\title{
Andrzej Lubiński
}

\section{Joachim Zdrenka (oprac.), Złotów 1370-2020 650-lecie miasta, Wydawnictwo Adam Marszałek, Toruń 2020, ss. 573}

Wydawnictwo Adam Marszałek funkcjonuje na rynku wydawnictw naukowych od 1990 roku. Publikuje prace naukowe z różnych dziedzin nauki praz wydaje czasopisma naukowe. Jednym ze stałych autorów jest prof.dr hab. Joachim Zdrenka. W roku 1976 ukończył on studia historyczne na UMK, w roku 1979 obronił pracę doktorska „Polityka zagraniczna książąt szczecińskich 1295-1411. Podjął pracę w Wojewódzkim Archiwum Państwowym w Gdańsku. Habilitację uzyskał w 1993 roku przedstawiając temat „Główne, Stare i młode Miasto Gdańsk i ich patrycjat 1342-1525". Od 1994 roku pracuje na WSP - obecnie jest to Uniwersytet Zielonogórski. Jest autorem wielu książek i artykułów w języku polskim i niemieckim. Problematyka badawcza koncentruje się na epigrafice Polski północno-zachodniej, dyplomatyce zachodniopomorskiej i pruskiej, edytorstwie i krytyce źródeł historycznych, historii średniowiecza Niemiec Północnych, regionu Hanzy, Pomorza, historii patrycjatu miast hanzeatyckich, historii Złotowa i ziemi złotowskiej. Przez kilka lat pracował w Marburgu, Bonn, Poczdamie.

Wiosną 2020 roku ukazała się w Wydawnictwie Adam Marszałek jego książka „Święta. Źródła i materiały do dziejów wsi 1419-2019”. W grudniu 2020 roku ukazała się monografia „Złotów 1370-2020. 650-lecie miasta". Składa się ze wstępu, części pierwszej, drugiej oraz wykazu literatury. Ze względu na to, że A. Kokowski opracował prehi- 
storię Złotowa i Krajny autor koncentruje się na dziejach miasta w średniowieczu. Przyjmuje się, że miasto lokowane zostało na prawie magdeburskim w 1370 roku. Pierwsza wzmianka pochodzi z kroniki Janka z Czarnkowa jaka zachowała się jedynie w kopiach XV-wiecznych i nazwa miasta jest tam zapisana po niemiecku jako Wlatow, chociaż ostatnio Sobiesław Szybkowski, historyk z Uniwersytetu Gdańskiego, znalazł dokument z 1372 roku, gdzie książę słupski Bogusław V pisze list do syna Kaźka z 23 lutego 1372 roku i wymienia w nim nazwę miasta Slottow. Złotów należał do obszaru Wielkopolsk,i administracyjne do województwa kaliskiego, starostwa nakielskiego. Autor wymienia wojewodów, starostów, kasztelanów jacy sprawowali władzę nad miastem i okolicznymi wsiami w okresie staropolskim. Początkowo miasto było w posiadaniu królewskim, następnymi właścicielami był ród Leszczyców, Bnińskich i Potulickich, Grudzińskich, Działyńskich. Po I rozbiorze Polski miasto znalazło się pod panowaniem pruskim i niemieckim. Zasługą autora jest ukazanie infrastruktury miasta od początku istnienia po współczesność.

Najcenniejsza jest część druga ujęta w hasła biograficzne osób mieszkających w tym mieście i różnych instytucji, jakie działały w XIX i XX wieku. Biogramy mieszczan złotowskich ukazują jak rozwijało się miasto w ostatnich dwustu latach pod względem gospodarczym, kulturalnym, politycznym. W rozwój miasta mieli wkład niemieccy, żydowscy i polscy mieszkańcy. Biogramy najważniejszych mieszkańców Złotowa pokazują, jakimi byli wybitnymi osobowościami i wpisali się trwale w dzieje miasta. Autor tu zachował właściwe proporcje. Joachim Zdrenka prostuje datę spalenia zamku złotowskiego, jaką podaje dwóch historyków Zbigniew Kuchowicz i Zdzisław Spieralski z 5 lipca (powoływali się na dziejopisa szwedzkiego Puffendorfa). Zdrenka przesuwa ją na 6 lipca 1657 roku, przywołując zapis z księgi miejskiej Gniezna, gdzie Jan Kolas, burmistrz i rajca Jakub Rabieszka zeznają pod przysięgą, iż Szwedzi przybyli do miasta 27 lipca a dzień później zdobyli zamek. Zeznający potwierdzają zniszczenie zamku i spalenie miasta na 6 lipca 1657 roku. Interesujące są informacje o drukowaniu pieniądza zastępczego po I wojnie światowej. Przy pisaniu biogramów korzystał autor z opracowań, jakie pozostawił po sobie patriota złotowski Erich Hoffmann - dziennikarz, wydawca autor kronik i zapisków. Mimo że był Niemcem to ciepło pisał o Polakach. 
Sprzedał swój dom dla polskiej szkoły w Złotowie. Nie nauczył się języka polskiego, zmarł u córki w Gdyni w 1961 roku. Interesujące są opisy wnętrz kościołów złotowskich - katolickiego i ewangelickiego. Ciekawie pisze o obiegu pocztowym w XIX i XX wieku. Dla mnie interesującą sprawą było opublikowanie zdjęcia nauczyciela i inspektora szkolnego Józefa Mozolewskiego, które posiadam w moim archiwum, na którym jest Mozolewski, ale nie potrafiłem go zidentyfikować. Biogramy osób i różnych instytucji, jakie funkcjonowały w mieście, są uzupełniane przez zdjęcia osób, budynków, ilustracji, reklam. Przyczyniają się one do podniesienia walorów tej cennej publikacji. Podana bibliografia na końcu książki jest imponująca. Joachim Zdrenka proponuje aby inny już autor zajmujący się historią najnowszą opracował dzieje miasta po 1945 roku, które on jedynie zasygnalizował ograniczając się do pokazania, jakich zniszczeń dokonano w pierwszych miesiącach 1945 roku. Zainteresowanie historią regionalną przez Joachima Zdrenkę spowodowało, że zajął się tematyką mało znaną nawet zawodowym historykom, jak lista poległych mieszkańców ziemi złotowskiej w I wojnie światowej oraz II wojny. Oddzielna pozycja to „Żydzi powiatu złotowskiego (1859) 1874-1945". Prace te wnoszą nowe ustalenia do historiografii zarówno polskiej jak i niemieckiej.

Wyrazy uznania dla Wydawnictwa Adam Marszałek - twarda okładka, szyte kartki, bardzo dobra jakość zdjęć. Miasto Złotów może się pochwalić znakomitym opracowaniem swoich dziejów przez jego honorowego obywatela. 